\title{
ANALISIS KUALITAS WEBSITE KYOU.ID TERHADAP KEPUASAN PEMBELI MENGGUNAKAN METODE IMPORTANCE-PERFOMANCE ANALYSIS
}

\author{
Devid Chia $^{1}$, Mesri Silalahi ${ }^{2}$ \\ 1,2 Prodi Sistem Informasi, Fakultas Teknik dan Komputer, Universitas Putera Batam
}

\section{Article Info:}

Dikirim: 16 Oktober 2019

Direvisi: 17 Desember 2019

Diterima: 31 Desember 2019

Tersedia Online: 31 Desember 2019

Penulis Korespondensi:

Devid Chia

Universitas Putera Batam, Batam, Indonesia

Email: devid22juni1997@gmail.com

\begin{abstract}
Abstrak: Kyou adalah toko yang bergerak dalam bidang penjualan figure dan merchandise yang berhubungan dengan anime, yang sekarang sudah membuka layanan penjualan secara online dengan menggunakan website yang dapat diakses di kyou.id. terdapat 3 fitur utama pada website kyou.id yang langsung berhubungan dalam proses penjualan, yaitu Pre-Order \& Back Order, Ready Stock, Unique Request. terdapat beberapa permasalahan pada website kyou.id yang peneliti anggap dapat mempengaruhi kualitas website kyou.id terhadap kepuasan dalam pembelian diantaranya: 1) kesulitan dalam pengubahan data pada website Kyou.id seperti pengubahan alamat, tempat tinggal, nomor telepon dan lain-lain. 2) Tidak adanya wishlist 3) Fitur bot chat pada Kyou.id kurang bisa menjawab pertanyaan. 4) Terdapat banyak barang yang sold out namun tetap ditampilkan. Tujuan yang ingin dicapai dari penelitian dengan metode Importance-performance analysis ini adalah: 1) Untuk menganalisis tingkat kualitas website kyou.id terhadap kepuasan pembeli dengan menggunakan metode importance-perfomance analysis. 2) menganalisis atribut kualitas website yang dianggap penting dalam menentukan kepuasan pembeli pada website kyou.id. Berdasarkan nilai analisis tingkat kesesuaian website kyou.id yaitu sebesar 88\%, nilai tingkat kesenjangan -0.51 maka tingkat kualitas website kyou.id masih belum memuaskan, atribut- atribut yang menentukan kualitas website kyou.id terhadap kepuasan pembeli terletak pada kuadran A dan kuadran $B$.
\end{abstract}

Kata kunci: kualitas website; kepuasan pembeli; importance-performance analysis.

\begin{abstract}
Kyou is the shop that engaged in selling figures and merchandise related to anime, which has now opened a sales service online using a website that can be accessed on kyou.id. there are 3 main features On the kyou.id website that are directly related to the sales process, namely Pre-Order \& Back Order, Ready Stock, Unique Request. Several problems are on the kyou.id website that considered could affect the quality of the kyou.id website including: 1) difficulties in changing the data on the Kyou.id website such as changing addresses, residences, telephone numbers and others. 2) There is no wishlist 3) The bot chat feature on Kyou.id is less able to answer questions. 4) There are many items that are sold out but still displayed. The objectives to be achieved from this study using impotance-performance analysis are: 1) To analyze the level of quality of the kyou.id website towards buyer satisfaction using the importance-perfomance analysis method. 2) analyzing website quality attributes which are considered important in determining buyer satisfaction on the kyou.id website. Based on the analysis value of the conformity level of the kyou.id website which is $88 \%$, the value of the gap level of -0.51 , the quality level of the kyou.id website is still unsatisfactory, the attributes that determine the quality of kyou.id's website to buyer satisfaction are in quadrant $A$ and quadrant $B$.
\end{abstract}

Keywords: website quality; customer satisfaction; importance-performance analysis. 


\section{PENDAHULUAN}

Kyou merupakan toko yang bergerak dibidang penjualan figure dan merchandise yang berhubungan dengan anime, dan sudah membuka layanan penjualan secara online dengan menggunakan website yang dapat diakses di kyou.id. Terdapat 3 fitur utama yang berhubungan langsung dalam proses penjualan, yaitu Pre-Order \& Back Order, Ready Stock, Unique Request. Berdasarkan 3 fitur utama, peneliti menerima data langsung dari founder kyou sendiri, pengunjung website kyou.id lebih sering menggunakan satu fitur untuk melakukan pembelian, yaitu unique request. Peneliti menemukan beberapa permasalahan pada website kyou.id yang dapat mempengaruhi kualitas website kyou.id diantaranya adalah untuk mengubah data pribadi seperti alamat,no. telepon harus menggunakan bot chat, tidak adanya wishlist sehingga pembeli tidak bisa membuat daftar barang yang akan dibeli nantinya, masih ditemukan barang yang sudahsold out pada menu ready stock sehingga pembeli mungkin akan merasakan sedikitnya barang yang benar-benar tersedia, friendship point yang terkumpul dari hasil pembelian barang tidak terlihat, sehingga pembeli tidak tahu pasti sudah berapa poin yang sudah terkumpul.

Importance - Performance Analysis pertama kali diperkenalkan oleh John A. Martilla dan John C. James pada tahun 1997 sebagai teknik analisis deskriptif yang digunakan untuk mengidentifikasi faktor yang perlu dan harus ditingkatkan kinerjanya untuk memenuhi kepuasan pembeli pada sebuah organisasi atau perusahaan. [1] Kelebihan metode IPA dibanding dengan metode yang lainnya adalah dapat mengambil suatu keputusan secara akurat dan cepat dalam mengatasi masalah yang berkaitan dengan ketidakpuasan pembeli terhadap pelayanan yang diberikan oleh website, sehingga diharapkan pelayanan yang diberikan kedepannya dapat memuaskan pembeli, serta tujuasn yang ingin dicapai dapat terpenuhi. fokuskan penelitian ini adalah pada analisis kualitas website kyou.id terhadap kepuasan pembeli menggunakan metode importance-performance analysis

\section{METODOLOGI PENELITIAN}

Analisis Metode IPA digunakan untuk mengidentifikasi atribut-atribut dari kualitas website kyou.id yang perlu dibutuhkan adanya pengembangan untuk meningkatkan kepuasan pembeli Adapun langkah - langkah Metode IPA yang akan digunakan adalah pengukuran variable menggunakan skala Likert [2], selanjutnya menentukan sampel dan jumlah sampel yang akan dilibatkan dengan menggunakan rumus penghitungan slovin[3]. dengan tingkat toleransi kesalahan/error sebesar $10 \%$. sehingga didapatkan jumlah responden dari penelitian ini adalah sebesar 100 responden, responden yang diambil merupakan orang yang pernah melakukan transaksi pembelian menggunakan website kyou.id, setelah itu penyebaran kuesioner melalui google form., setelah data kuesioner terpenuhi barulah melakukan penghitungan distribusi perhitungan skor tingkat kinerja dan tingkat kepentingan, dilakukan juga perhitungan tingkat keseusaiannya, setelah itu dilakukannya perhitungan tingkat kesenjangan(GAP) untuk mengukur perbedaan kepuasan pembeli dan kinerja dari website. Dan yang terakhir adalah penentuan kuadran IPA.

\subsection{Kuesioner}

Kuisioner berisikan daftar pernyataan yang disusun oleh penulis pada Tabel 1. Pertanyaan-pertanyaan pada kuisioner untuk mengetahui kualitas website kyou.id terhadap kepuasan pembeli, yaitu[4] (1) kemampuan seorang pengguna websitedalammencari cara untuk menggunakan websitedengan efektif dan benar (usability), (2) kemudahan sistem navigasi untuk dipelajari dan dipahami oleh pengunjung, agar dapat menemukan halamanhalaman yang lebih spesifik yang berada pada website (navigation sistem), (3) penentuan secara grafis, pewarnaan, tata letak, bentuk dan typografi yang baik (graphic design), (4) isi yang bermanfaat meliputi yang dapat dilihat maupun dirasakan (content), (5) penyesuaian website terhadap berbagai browser dan juga plug-in yang digunakan (compatibility), (6) lama waktu yang diperlukan unutk menampilkan isi/konten (loading time), (7) seberapa baik fungsi pemrograman yang ada pada website (functional), (8) wujud perasaan pembeli ketika telah melakukan sebuah perbandingan kinerja dengan harapan (kepuasan pembeli)[5]. 
Tabel 1. Kuesioner

\begin{tabular}{|c|c|c|}
\hline Variabel & Indikator & Kode \\
\hline \multirow{5}{*}{ Usability } & Website kyou.id mudah dipelajari pada saat di akses dan digunakan & US1 \\
\hline & $\begin{array}{l}\text { Website kyou.id sudah efisien pada saat digunakan untuk membeli barang/item } \\
\text { hobby }\end{array}$ & US2 \\
\hline & $\begin{array}{l}\text { Website kyou.id mudah diingat, sehingga dapat membuat ingin kembali } \\
\text { berkunjung ke kyou.id }\end{array}$ & US3 \\
\hline & $\begin{array}{l}\text { Fitur pada website kyou.id masih sulit pada saat digunakan sehingga dapat } \\
\text { membuat pengunjung melakukan error/kesalahan }\end{array}$ & US4 \\
\hline & $\begin{array}{l}\text { Website kyou.id dapat memberikan kepuasan dalam mencari dan membeli } \\
\text { barang/item }\end{array}$ & US5 \\
\hline \multirow{4}{*}{$\begin{array}{l}\text { Navigation } \\
\text { System }\end{array}$} & $\begin{array}{l}\text { Sistem navigasi yang disediakan pada website kyou.id sudah memudahkan untuk } \\
\text { mengunjungi halaman yang lebih spesifik }\end{array}$ & NS1 \\
\hline & Tata letak sistem navigasi pada website kyou.id mudah di mengerti & NS2 \\
\hline & $\begin{array}{l}\text { Semua link yang terhubung pada sistem navigasi website kyou.id sudah sesuai } \\
\text { dengan keterangan }\end{array}$ & NS3 \\
\hline & $\begin{array}{l}\text { Sistem navigasi pada website kyou.id bisa digunakan untuk melakukan pencarian } \\
\text { halaman barang/item lebih dalam }\end{array}$ & NS4 \\
\hline \multirow{3}{*}{$\begin{array}{l}\text { Graphic } \\
\text { Design }\end{array}$} & $\begin{array}{l}\text { Desain yang digunakan pada website kyou.id menimbulkan kenyamanan dalam } \\
\text { menggunakan dan membeli }\end{array}$ & GD1 \\
\hline & Kombinasi warna pada website kyou.id menarik secara visual/penlihatan & GD2 \\
\hline & Pada website kyou.id gambar barang/item yang dijual sudah sesuai & CT1 \\
\hline Content & $\begin{array}{l}\text { Multimedia yang digunakan (*contohnya animasi) pada website kyou.id sudah } \\
\text { mendukung isi konten }\end{array}$ & CT2 \\
\hline \multirow{2}{*}{ Compatibility } & $\begin{array}{l}\text { Website kyou.id dapat diakses dengan baik di berbagai browser (*seperti mozilla } \\
\text { firefox, google chrome, dll) }\end{array}$ & $\mathrm{CP} 1$ \\
\hline & $\begin{array}{l}\text { Website kyou.id dapat diakses dengan baik di berbagai perangkat }\left({ }^{*} \text { seperti }\right. \\
\text { android, iphone, feature phone nokia, laptop, komputer) }\end{array}$ & $\mathrm{CP} 2$ \\
\hline \multirow[b]{2}{*}{ Loading Time } & kyou.id tidak membutuhkan waktu yang lama untuk diakses & LT1 \\
\hline & $\begin{array}{l}\text { Ketika waktu tunggu website kyou.id terlalu lama untuk diakses tetap } \\
\text { memutuskan untuk mengunjungi kyou.id }\end{array}$ & LT2 \\
\hline \multirow{3}{*}{ Functional } & website kyou.id sudah dinamis dan interaktif dalam menjalankan fungsinya & $\mathrm{FC} 1$ \\
\hline & $\begin{array}{l}\text { Fitur chat yang dihadirkan pada website kyou.id mampu mengajak pengunjung } \\
\text { website berkomunikasi secara langsung }\end{array}$ & $\mathrm{FC} 2$ \\
\hline & Semua fitur yang dihadirkan pada website kyou.id dapat berfungsi dengan baik & FC3 \\
\hline \multirow{5}{*}{$\begin{array}{l}\text { Kepuasan } \\
\text { Pembeli }\end{array}$} & $\begin{array}{l}\text { Kinerja website kyou.id dalam memperkenalkan barang/item yang dijual sudah } \\
\text { baik }\end{array}$ & KP1 \\
\hline & $\begin{array}{l}\text { Website kyou.id sudah memiliki nilai tambah yang mendukung proses pembelian } \\
\text { barang/item }\end{array}$ & KP2 \\
\hline & $\begin{array}{l}\text { Barang/item yang dijual pada website kyou.id sudah sesuai dengan spesifikasi } \\
\text { yang ada }\end{array}$ & KP3 \\
\hline & $\begin{array}{l}\text { Pada website kyou.id terdapat informasi yang ditampilkan tentang kualitas } \\
\text { sehingga dapat menjadi daya tarik tersendiri untuk membeli barang/item yang } \\
\text { ditawarkan/jual }\end{array}$ & KP4 \\
\hline & $\begin{array}{l}\text { Website kyou.id, pihak kyou dapat membangun citra reputasi dan tanggung jawab } \\
\text { kepada pengunjung dan pembeli }\end{array}$ & KP5 \\
\hline
\end{tabular}

\section{HASIL DAN PEMBAHASAN}

Dalam penelitian ini, peneliti mengumpulkan data dengan cara menyebarkan kuesioner secara onlinedalam bentuk google form kepada pengguna dan pembeli yang menggunakan website kyou.id. Hal ini dilakukan untuk mendapatkan informasi dan respon yang akan dijadikan sebagai data didalam penelitian ini, kuesioner yang disebarkan terdiri dari dua bagian yaitu tentang kinerja dan tentang kepentingan website kyou.id. Untuk melengkapi penelitian ini, peneliti mengambil sampel sebanyak 100 responden. Karakteristik responden yang sudah disesuaikan dengan kriteria inklusi yang sudah ditetapkan oleh peneliti. 


\subsection{Penghitungan Skot Tingkat Kinerja}

Setiap pertanyaan dalam kuesinoer diberi skor, Jawaban sangat tidak penting dan sangat tidak sesuai kinerja diberi skor 1, jawaban kurang penting dan kurang sesuai kinerja diberi skor 2, jawaban cukup diberi skor 3 , jawaban penting dan sesuai kinerja diberi skor 4 dan jawaban sangat penting dan sangat sesuai kinerja diberi skor 5. diperoleh bahwa terdapat 13 atribut yang sudah dianggap memenuhi atau kinerja website sudah baik oleh responden yang ditunjukkan dengan penilaian rata-rata skor atribut yang berada diatas rata-rata skor tingkat kinerja. Penghitungan skor tingkat kinerja ditunjukkan pada tabel 2.

Tabel 2. Distribusi penghitungan skor tingkat kinerja

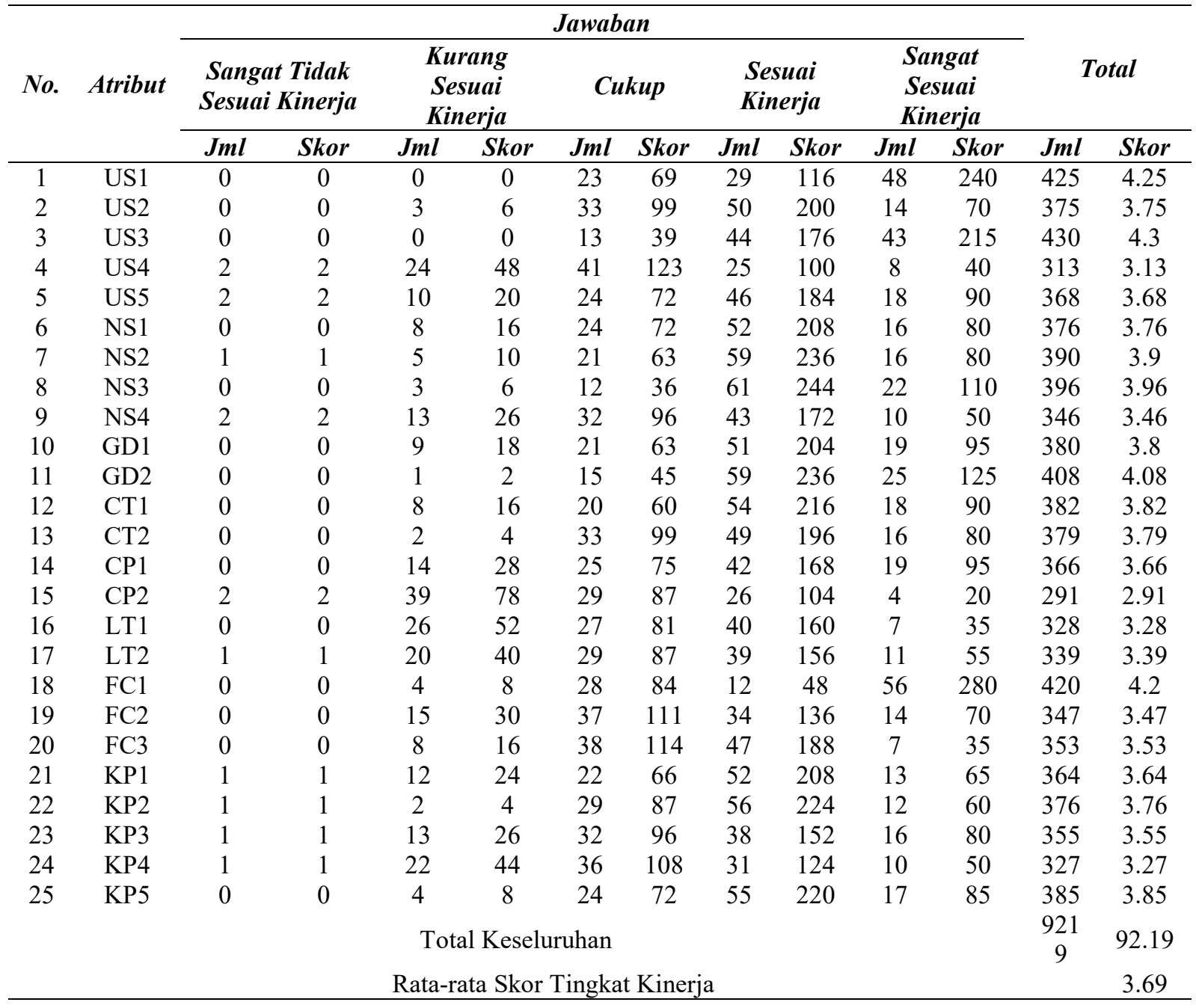

\subsection{Penghitungan Skor Tingkat Kepentingan}

Diperoleh bahwa terdapat 14 atribut yang berada diatas rata-rata skor tingkat kepentingan yang dianggap sangat penting dan diharapkan oleh responden yang ditunjukkan dengan penilaian rata-rata skor atribut. Penghitungan skor tingkat kinerja dapat dilihat pada tabel 3. 
Tabel 3. Distribusi penghitungan skor tingkat kinerja

\begin{tabular}{|c|c|c|c|c|c|c|c|c|c|c|c|c|c|}
\hline \multirow{3}{*}{ No. } & \multirow{3}{*}{ Atribut } & \multicolumn{10}{|c|}{ Jawaban } & \multirow{2}{*}{\multicolumn{2}{|c|}{ Total }} \\
\hline & & \multicolumn{2}{|c|}{$\begin{array}{c}\text { Sangat } \\
\text { TidakPenting }\end{array}$} & \multicolumn{2}{|c|}{$\begin{array}{l}\text { Kurang } \\
\text { Penting }\end{array}$} & \multicolumn{2}{|c|}{ Cukup } & \multicolumn{2}{|c|}{ Penting } & \multicolumn{2}{|c|}{$\begin{array}{l}\text { Sangat } \\
\text { Penting }\end{array}$} & & \\
\hline & & $J m l$ & Skor & $J m l$ & Skor & $\mathrm{Jml}$ & Skor & $J m l$ & Skor & $\mathrm{Jml}$ & Skor & $J m l$ & Skor \\
\hline 1 & US1 & 0 & 0 & 2 & 4 & 14 & 42 & 30 & 120 & 54 & 270 & 436 & 4.36 \\
\hline 2 & US2 & 0 & 0 & 0 & 0 & 12 & 36 & 36 & 144 & 52 & 260 & 440 & 4.4 \\
\hline 3 & US3 & 0 & 0 & 4 & 8 & 15 & 45 & 32 & 128 & 49 & 245 & 426 & 4.26 \\
\hline 4 & US4 & 0 & 0 & 0 & 0 & 25 & 75 & 42 & 168 & 33 & 165 & 408 & 4.08 \\
\hline 5 & US5 & 0 & 0 & 0 & 0 & 32 & 96 & 33 & 132 & 35 & 175 & 403 & 4.03 \\
\hline 6 & NS1 & 0 & 0 & 1 & 2 & 29 & 87 & 31 & 124 & 39 & 195 & 408 & 4.08 \\
\hline 7 & NS2 & 0 & 0 & 5 & 10 & 16 & 48 & 39 & 156 & 40 & 200 & 414 & 4.14 \\
\hline 8 & NS3 & 0 & 0 & 0 & 0 & 20 & 60 & 34 & 136 & 46 & 230 & 426 & 4.26 \\
\hline 9 & NS4 & 0 & 0 & 0 & 0 & 38 & 114 & 29 & 116 & 33 & 165 & 395 & 3.95 \\
\hline 10 & GD1 & 0 & 0 & 3 & 6 & 36 & 108 & 31 & 124 & 30 & 150 & 388 & 3.88 \\
\hline 11 & GD2 & 0 & 0 & 3 & 6 & 51 & 153 & 18 & 72 & 28 & 140 & 371 & 3.71 \\
\hline 12 & $\mathrm{CT} 1$ & 0 & 0 & 0 & 0 & 16 & 48 & 33 & 132 & 51 & 255 & 435 & 4.35 \\
\hline 13 & СТ2 & 0 & 0 & 8 & 16 & 20 & 60 & 34 & 136 & 38 & 190 & 402 & 4.02 \\
\hline 14 & $\mathrm{CP} 1$ & 0 & 0 & 0 & 0 & 14 & 42 & 30 & 120 & 56 & 280 & 442 & 4.42 \\
\hline 15 & $\mathrm{CP} 2$ & 0 & 0 & 0 & 0 & 18 & 54 & 35 & 140 & 47 & 235 & 429 & 4.29 \\
\hline 16 & LT1 & 0 & 0 & 4 & 8 & 25 & 75 & 35 & 140 & 36 & 180 & 403 & 4.03 \\
\hline 17 & LT2 & 0 & 0 & 0 & 0 & 23 & 69 & 29 & 116 & 48 & 240 & 425 & 4.25 \\
\hline 18 & $\mathrm{FC} 1$ & 0 & 0 & 7 & 14 & 24 & 72 & 35 & 140 & 34 & 170 & 396 & 3.96 \\
\hline 19 & $\mathrm{FC} 2$ & 0 & 0 & 0 & 0 & 17 & 51 & 33 & 132 & 50 & 250 & 433 & 4.33 \\
\hline 20 & $\mathrm{FC} 3$ & 0 & 0 & 0 & 0 & 6 & 18 & 44 & 176 & 50 & 250 & 444 & 4.44 \\
\hline 21 & KP1 & 0 & 0 & 0 & 0 & 14 & 42 & 35 & 140 & 51 & 255 & 437 & 4.37 \\
\hline 22 & KP2 & 0 & 0 & 6 & 12 & 12 & 36 & 43 & 172 & 39 & 195 & 415 & 4.15 \\
\hline 23 & KP3 & 0 & 0 & 0 & 0 & 5 & 15 & 46 & 184 & 49 & 245 & 444 & 4.44 \\
\hline 24 & KP4 & 0 & 0 & 2 & 4 & 14 & 42 & 35 & 140 & 49 & 245 & 431 & 4.31 \\
\hline 25 & KP5 & 0 & 0 & 0 & 0 & 8 & 24 & 41 & 164 & 51 & 255 & 443 & 4.43 \\
\hline \multicolumn{12}{|c|}{ Total Keseluruhan } & 10494 & 104.94 \\
\hline \multicolumn{12}{|c|}{ Rata-rata Skor Tingkat Kepentingan } & & 4.2 \\
\hline
\end{tabular}

\subsection{Penghitungan Tingkat Kesesuaian}

Tabel 4. Tabel tingkat kesesuaian

\begin{tabular}{cccccc}
\hline No. & Atribut & $\begin{array}{c}\text { Total Skor Tingkat } \\
\text { Kinerja }\end{array}$ & $\begin{array}{c}\text { Total Skor Tingkat } \\
\text { Kepentingan }\end{array}$ & $\begin{array}{c}\text { Tingkat } \\
\text { Kesesuaian }\end{array}$ & $\%$ \\
\hline 1 & US1 & 425 & 436 & 0.97 & 97 \\
2 & US2 & 375 & 440 & 0.85 & 85 \\
3 & US3 & 430 & 426 & 1.01 & 101 \\
4 & US4 & 313 & 408 & 0.77 & 77 \\
5 & US5 & 368 & 403 & 0.91 & 91 \\
6 & NS1 & 376 & 408 & 0.92 & 92 \\
7 & NS2 & 390 & 414 & 0.94 & 94 \\
8 & NS3 & 396 & 426 & 0.93 & 93 \\
9 & NS4 & 346 & 395 & 0.88 & 88 \\
10 & GD1 & 380 & 388 & 0.98 & 98 \\
11 & GD2 & 408 & 371 & 1.1 & 110 \\
12 & CT1 & 382 & 435 & 0.88 & 88 \\
\hline
\end{tabular}




\begin{tabular}{cccccc}
\hline No. & Atribut & $\begin{array}{c}\text { Total Skor Tingkat } \\
\text { Kinerja }\end{array}$ & $\begin{array}{c}\text { Total Skor Tingkat } \\
\text { Kepentingan }\end{array}$ & $\begin{array}{c}\text { Tingkat } \\
\text { Kesesuaian }\end{array}$ & $\%$ \\
\hline 13 & CT2 & 379 & 402 & 0.94 & 94 \\
14 & CP1 & 366 & 442 & 0.83 & 83 \\
15 & CP2 & 291 & 429 & 0.68 & 68 \\
16 & LT1 & 328 & 403 & 0.81 & 81 \\
17 & LT2 & 339 & 425 & 0.8 & 80 \\
18 & FC1 & 420 & 396 & 1.06 & 106 \\
19 & FC2 & 347 & 433 & 0.8 & 80 \\
20 & FC3 & 353 & 444 & 0.8 & 80 \\
21 & KP1 & 364 & 437 & 0.83 & 83 \\
22 & KP2 & 376 & 415 & 0.91 & 91 \\
23 & KP3 & 355 & 444 & 0.8 & 80 \\
24 & KP4 & 327 & 431 & 0.76 & 76 \\
25 & KP5 & 385 & 443 & 0.87 & 87 \\
& & Rata-rata Total & & 0.88 & 88 \\
\hline
\end{tabular}

Hasil tingkat kesesuaian dari 25 atribut kualitas website kepuasan pembeli didapat dari hasil penghitungan skor kuesioner akhir tingkat kinerja $\left(\sum X\right)$ dibagi dengan hasil dari penghitungan skor kuesioner akhir tingkat kepentingan $\left(\sum \mathrm{Y}\right)$ setelah didapatkan hasilnya, lalu dikalikan 100\%.[6] Dapat diketahui atribut yang terendah sebesar $68 \%$ adalah compatibility. Hal ini berarti bahwa artibut tersebut dirasa masih belum memuaskan pembeli ketika dikunjungi dan diakses pada browser smartphone. Sedangkan untuk atribut yang mendapat nilai tingkat kesesuaian tertinggi sebesar $110 \%$ dan atribut tersebut melebihi harapan dari pengunjung dan pembeli adalah graphic design. Hal ini menunjukkan bahwa pihak kyou memperhatikan komposisi design dan pengaturan tata letak yang baik untuk memperindah sekaligus mendukung performa dalam melayani setiap pengakses sehingga pengakses website kyou.id merasa nyaman dengan melakukan pembelian.

Rata-rata dari hasil penghitungan tingkat kesesuaian responden adalah $88 \%$, hasil nilai rata- rata tingkat kesesuaian ini didapat dari jumlah seluruh atribut kemudian hasilnya dibagi 25 atribut tersebut. Dapat dikatakan kinerja dari sebagian besar atribut dapat memenuhi harapan dari pembelinya, namun perlu adanya peningkatan kinerja website.

\subsection{Analisis Tingkat Kesenjangan (GAP)}

Nilai kesenjangan pada website kyou.id didapatkan dari selisih antara nilai kinerja dengan nilai kepentingan[6]. Hasil Penghitungan Tingkat Kesenjangan (GAP) dapat dilihat pada table 5:

Tabel 5. Tabel kesenjangan (GAP)

\begin{tabular}{ccc}
\hline Rata-rata Kinerja / Perf(i) & Rata-rata Kepentingan / Imp(i) & $\begin{array}{l}\text { Qi } \\
\text { (Gap) }\end{array}$ \\
\hline 3.69 & 4.2 & -0.51 \\
\hline
\end{tabular}

Berdasarkan tabel diatas, hasil dari nilai kesenjangan pada website kyou.id adalah $(-0.51<0)$, ini menunjukkan bahwa kinerja sistem saat ini masih belum terlalu sesuai dengan harapan penggunanya. 


\subsection{Analisis Kuadran IPA}

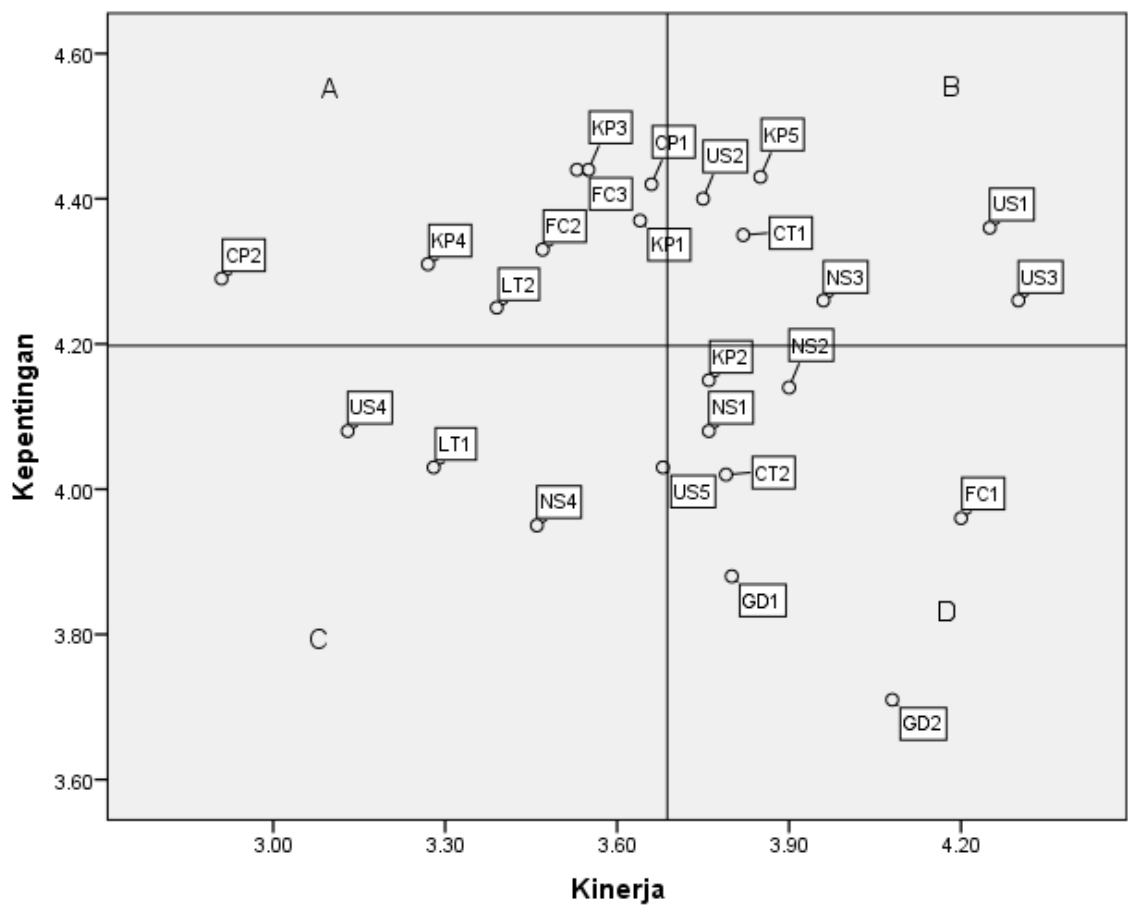

Gambar 1. Kuadran IPA

Dari diagram kartesius di atas didapatkan pembagian atribut yang diteliti. Atribut terbagi menjadi 4 kuadran, yaitu kuadran A, kuadran B, kuadran C, dan kuadran D. Setiap atribut dibutuhkan sebagai strategi untuk meningkatkan kepuasan peengujung dan pembeli terhadap kualitas website kyou.id. Kuadran yang paling membutuhkan sebuah perbaikan adalah kuadran A[7], dimana kuadran A merupakan Prioritas Tinggi untuk diperbaiki, selanjutnya diikuti dengan penyeibangan kuadran D karena kinerja yang cenderung berlebihan dari sebuah kepentingan, dan setelah itu kuadran Cyang merupakan sebuah prioritas rendah.

\section{KESIMPULAN}

Berdasarkan hasil penelitian dan pembahasan yang telah dilakukan, maka dapat diambil sebuah kesimpulan adalah sebagai berikut:

1) Berdasarkan nilai analisis tingkat kesesuaian website kyou.id yaitu sebesar 88\%, dan nilai tingkat kesenjangan -0.51 maka tingkat kualitas website kyou.id masih perlu ditingkatkan;

2) Berdasarkan hasil pada diagram kartesius,kuadran yang menentukan atribut kualitas website kyou.id terhadap kepuasan pembeli adalahkuadran A dan kuadran B.

3) Terdapat 8 Atribut pada kuadran A (high importance-low performance) atau prioritas utama untuk ditingkatkan yaitu: a. kompatibilitas pengaksesan website kyou.id pada berbagai browser; b. kompatibilitas pengaksesan website kyou.id pada berbagai perangkat; c. memutuskan untuk tetap melanjutkan mengakses website ketika waktu tunggu terlalu lama; d. fitur chat yang dihadirkan; e. dari seluruh fitur yang dihadirkan masih ada beberapa fitur yang dirasa perlu ditingkatkan lagi; f. kinerja website kyou.id dalam memperkenalkan barang/item; g. kesesuain barang/item yang dijual dengan deskripsi; h. informasi tentang kualitas barang/item.

4) Terdapat 6 Atribut yang berada di kuadran B (high importance-high perfomance) atau pertahankan kinerja yaitu :a. mudah dipelajari; b.efisiensi; c. mudah diingat; d. keseuaian gambar; e. keseuaian link; f.citra reputasi/tanggug jawab.

\section{DAFTAR PUSTAKA}

[1] A. Al Baiti, Suprapto, and A. Rachmadi, "Pengukuran Kualitas Layanan Website Dinas Pendidikan Kota Malang Dengan Menggunakan Metode Webqual 4 . 0 dan IPA," J. Pengemb. Teknol. Inf. dan Ilmu Komput., vol. 1, no. 9, pp. 885-892, 2017.

[2] R. Nugraha, A. Harsono, and Adianto, "Usulan Peningkatan Kualitas Pelayanan Jasa pada Bengkel ' $X$ ' Berdasarkan Hasil Matrix Importance-Performance Analysis* (Studi Kasus di Bengkel AHASS PD. Sumber Motor Karawang) RIZAL,” J. Online Inst. Teknol. Nas., vol. 1, no. 3, pp. 221-231, 2014. 
[3] W. Purnomo and D. Riandadari, "ANALISA KEPUASAN PELANGGAN TERHADAP BENGKEL DENGAN METODE IPA ( IMPORTANCE PERFORMANCE ANALYSIS ) DI PT . ARINA PARAMA JAYA GRESIK," JTM, vol. 03, no. 3, pp. 54-63, 2015.

[4] W. Hardyanto, A. Adhi, and A. Purwinarko, "Usability Laman Penerimaan Mahasiswa Baru UNNES," Sci. J. Informatics, vol. 3, no. 1, pp. 28-35, 2016.

[5] J. O. Ong and J. Pambudi, "ANALISIS KEPUASAN PELANGGAN DENGAN IMPORTANCE PERFORMANCE ANALYSIS DI SBU LABORATORY CIBITUNG PT SUCOFINDO (PERSERO)," JATI Undip, vol. IX, no. 1, pp. 177-193, 2014.

[6] W. S. Fatmala, Suprapto, and A. Rachmadi, "Analisis Kualitas Layanan Website E-Commerce Berrybenka Terhadap Kepuasan Peangunjung Menggunakan Metode WebQual 4.0 dan Importance Performance Analysis (IPA)," J. Pengemb. Teknol. Inf. dan Ilmu Komput., vol. 2, no. 1, pp. 175-183, 2018.

[7] I. Dalilah, A. Kusyanti, and A. D. Herlambang, "Evaluasi Kualitas Layanan Website PT. Kereta Api Indonesia (Persero) terhadap Kepuasan Pengguna Menggunakan Webqual 4.0 dan ImportancePerformance Analysis (IPA),” J. Pengemb. Teknol. Inf. dan Ilmu Komput., vol. 2, no. 1, pp. 288-295, 2018. 